\title{
Peertechz
}

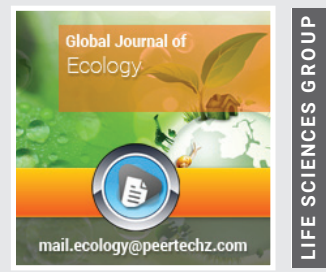

\section{The importance of spider diversity in agroecosystems and the effect of pesticides}

Received: 22 September, 2020

Accepted: 30 September, 2020

Published: 01 October, 2020

*Corresponding author: Marco Antonio Benamú $\mathrm{P}$, Centro Universitario de Rivera (Universidad de la República), Rivera, Uruguay,

E-mail:mbenamu@cur.edu.uy

https://www.peertechz.com

Check for updates

\section{Marco Antonio Benamú P*}

Centro Universitario de Rivera (Universidad de la República), Rivera, Uruguay

Several studies show that spiders represent the largest biomass of predatory arthropods in different agroecosystems, which added to their habits increase their potential as the main consumer of certain pest species [1-4]. Their constant and abundant presence during all phases of the development of a crop allows them to act as effective natural enemies of phytophagous insects [3-9], due to the ability to colonize different agroecosystems $[8,10,11]$. In addition to being indicators of the quality of the environment in agricultural fields $[12,13]$, they constitute the dominant component of the assembly of generalist predators [14], which includes not only adult insects, but also eggs and larvae (Lepidoptera and Coleoptera) $[1,10,15,16]$. Studies aimed at obtaining information on spiders in agroecosystems, as pest controllers, have increased, demonstrating their potential to be used as biological control agents in Integrated Pest Management (IPM) $[2,3,9,17,18,19,20-23]$.

But the use of pesticides (insecticides, herbicides and fungicides), generate a decrease in the biodiversity of spiders, producing effects on ambulatory speed and preys that may be exposed to residues that would be affecting mortality of spiders [24-29]. Therefore, their populations decrease after the application of these, causing a combination of effects that include death directly or an indirect lethal action (changes in physiological behavior, constructive behavior), migration and sublethal effects such as the decrease in reproductive capacities and predators or impacts on food quality and supplies, being quantifiable in the case of weavers, being able to provide information on the xenobiotic [24,30,31].These chemicals can affect the behavior of nerve structures and behavior, observable in the structures of the spider silk [32]. Although sublethal effects of pesticides have received less attention than the lethal effects, they are relevant from an ecological point of view, since reducing the performance of populations can create risk for the conservation of biodiversity of spiders.

Changing some practices in agro-ecosystems, would minimize the negative impact on the diversity of spiders, considering them as reservoirs of native species and biological corridors between natural environments. In this way, the knowledge of the spider community can be used to evaluate the impact that agroecosystems produce in native biological communities and become new information resources for the environmental certification of agricultural practices [33], reducing farmers the indiscriminate use of pesticides and improving their agricultural practices.

\section{References}

1. Mansour F, Rosen D, Shulov A (1980) A survey of spider populations (Araneae) in sprayed and unsprayed apple orchards in Israel and their ability to feed on larvae of Spodoptera littoralis (Boisd.). Ecol Applic 1: 189-197. Link: https://bit.ly/3|44rrD

2. Benamú M (1999) Estudio preliminar de la araneofauna presente en mandarina cultivada en Vitarte, Lima, Perú. Rev Per Ent 41: 154-157. Link: https://bit.ly/2GcCu1N

3. Benamú M, Aguilar P (2001) Araneofauna presente en huertos de manzano del Valle de Mala, lima, Perú Rev Per Ent 42: 199-210. Link: https://bit.ly/3n3ICvc

4. Pearce S, Hebron W, Raven R, Zalucki M, Hassan E (2004) Spider fauna of soybean crops in south-east Queensland and their potential as predators of Helicoverpa spp. (Lepidoptera: Noctuidae). Aust J Entomol 43: 57-65. Link: https://bit.ly/2SbKqTr

5. Aguilar PPG (1989) Las arañas como controladoras de plagas insectiles en la agricultura peruana. Rev Per Ent 31: 1-8. Link: https://bit.ly/348k4Yg

6. Nyffeler M, Sterling W, Dean D (1994) Insectivorous activities of spiders in United States field crops. J Appl Entomol 118: 113-128. Link: https://bit.ly/33cQpOH 
7. Benamú M (2004) Estudio comparativo de la diversidad de arañas de un campo en abandono y un cultivo convencional de limonero (Citrus limon [L.] Burm.) en Rincón del Cerro, Montevideo, Uruguay. Dissertation, Universidad de la República, Facultad de Ciencias, Montevideo, Uruguay

8. Pino B, Antonio M (2010) Composición y estructura de la comunidad de arañas en el sistema de cultivo de soja transgénica. Dissertation, Universidad Nacional de La Plata, Facultad de Ciencias Naturales y Museo, La Plata, Argentina. Link: https://bit.ly/3l3C3pB

9. Benamú M, Lacava M, García L, Santana M, Viera C (2017) Spiders asociated with agroecosystems: roles and perspectives. In: Behaviour and Ecology of Spiders. Contributios from the Neotropical Region. Ed.: Springer: 275 - 302. Link: https://bit.ly/3io7wku

10. Riechert S, Lockley T (1984) Spiders as biological control agents. Annu Rev Entomol 29: 299-320. Link: https://bit.ly/30mVFNn

11. Symondson W, Sunderland K, Greenstone M (2002) Can generalist predators be effective biocontrol agents?. Annu Rev Entomol 47: 561-594. Link: https://bit.ly/3clSjcp

12. Clausen IHS (1986) The use of spiders (Araneae) as ecological indicators. Bull Br Arachnol Soc 7: 83-86. Link: https://bit.ly/2SbJU82

13. Marc P, Canard A, Ysnel F (1999) Spiders (Araneae) useful for pest limitation and bioindication. Agric Ecosyst Environ 74: 229-273. Link: https://bit.ly/348xJyk

14. Sunderland K (1999) Mechanisms underlying the effects of spiders on pest populations. J Arachnol 27: 308-316. Link: https://bit.ly/348ktdb

15. Nyffeler M, Breene R, Dean D, Sterling W (1990) Spiders as predators of arthropod eggs. J Appl Ent 109: 490-501. Link: https://bit.ly/33fWbig

16. Young O, Edward G (1990) Spiders in United States field crops and their potential effect on crop pests. J Arachnol 18: 1-27. Link: https://bit.ly/36hE6lw

17. Morris T, Symondson W, Kidd N, Campos M (1999) Las arañas y su incidencia sobre Prays oleae en el olivar. Bol. San. Veg. Plagas 25: 475-489. Link: https://bit.ly/2GiVAn5

18. Ghavami S (2008) The potential of predatory spiders as biological control agents of cotton pests in Tehran provinces of Iran. Asian J Expl Sci 22: 303306. Link: https://bit.ly/2GmcLEa

19. Zrubecz P, Toth F, Nagy A (2008) Is Xysticus kochi (Araneae: Thomisidae) an efficient indigenous biocontrol agent of Frankliniella occidentalis (Thysanoptera: Thripidae)?. BioControl 53: 615-624. Link: https://bit.ly/2SfKj9A

20. Armendano A, González A (2009) Comunidad de arañas (Arachnida, Araneae) del cultivo de alfalfa (Medicago sativa) en Buenos Aires Argentina. Revista de Biología Tropical 58: 747-757. Link: https://bit.ly/33kBfXi

21. Monzó C, Mollá O, Castañera P, Urbaneja A (2009) Activity-density of Pardosa cribata in Spanish citrus orchards and its predatory capacity on Ceratitis capitata and Myzus persicae. BioControl 54: 393-402. Link: https://bit.ly/30qVL6G

22. Almada M, Sosa M, González A (2012) Araneofauna (Arachnida: Araneae) en cultivos de algodón (Gossypium hirsutum) transgénicos y convencionales en el norte de Santa Fe Argentina. Revista de Biología Tropical 60: 611-623. Link: https://bit.ly/3lb0rp1

23. Avalos G, Bar G, Oscherov E, González A (2013) Diversidad de Araneae en cultivos de Citrus sinensis de la Provincia de Corrientes (Argentina). Revista de Biología Tropical 61:1243-1260. Link: https://bit.ly/3n88xAF
24. Benamú M, Schneider M, Sánchez N (2010) Effects of the herbicide glyphosate on biological attributes of Alpaida veniliae (Araneae, Araneidae), in laboratory. Chemosphere 78: 871-876. Link: https://bit.ly/2HK1Kx1

25. Benamú M, Schneider M, González A, Sánchez N (2013) Short and long term effects of three neurotoxic insecticides on biological and behavioural attributes of the orb-web spider Alpaida veniliae (Araneae, Araneidae) implications for IPM programs. Ecotoxicology 22:1155-1164. Link: https://bit.ly/3I2s2IW

26. Benamú M, Lacava M, García LF, Santana M, Fang J, et al. (2017) Nanostructural and mechanical property changes to spider silk as a consequence of insecticide exposure. Chemosphere 181: 241-249. Link: https://bit.ly/3kXrKmO

27. Pekár S (2012) Spiders (Araneae) in the pesticide world: An ecotoxicologica review. Pest Management Science 68: 1438-1446. Link: https://bit.ly/2GbdyYR

28. Lacava M, García L, Viera C, Michalko R (2020) The pest-specific effects of glyphosate on functional response of a wolf spider. Chemosphere 262 127785. Link: https://bit.ly/3l1wQ1e

29. KorenkoS, Saska P, Kysilková1 K, Řezáč M, Heneberg P (2019) Prey contaminated with neonicotinoids induces feeding deterrent behavior of a common farmland spider. Sci Rep 9: 15895. Link: https://bit.ly/3joVVmA

30. Benamú M, Schneider M, Pineda S, Sánchez N, González A (2007) Sublethal effects of two neurotoxican insecticides on Araneus pratensis (Araneae: Araneidae). Comm Appl Biol Sci 72: 557-559. Link: https://bit.ly/3iigH5X

31. Benamú M, Schneider M, González A, Sánchez N (2013) Short and long term effects of three neurotoxic insecticides on biological and behavioural attributes of the orb-web spider Alpaida veniliae (Araneae, Araneidae) implications for IPM programs. Ecotoxicology 22:1155-1164. Link: https://bit.ly/3I2s2IW

32. Benamú M, Lacava M, García LF, Santana M, Fang J, et al. (2017) Nanostructural and mechanical property changes to spider silk as a consequence of insecticide exposure. Chemosphere 181: 241-249. Link: https://bit.ly/3kXrKmO

33. Simó M, Laborda A, Jorge C, Castro M (2011) Las arañas en agroecosistemas: bioindicadores terrestres de calidad ambiental. Innotec 6: 51-55. Link: https://bit.ly/33mArRG

\section{Discover a bigger Impact and Visibility of your article publication with} Peertechz Publications

\section{Highlights}

* Signatory publisher of ORCID

* Signatory Publisher of DORA (San Francisco Declaration on Research Assessment)

* Articles archived in worlds' renowned service providers such as Portico, CNKI, AGRIS, TDNet, Base (Bielefeld University Library), CrossRef, Scilit, J-Gate etc.

* Journals indexed in ICMJE, SHERPA/ROMEO, Google Scholar etc.

* OAI-PMH (Open Archives Initiative Protocol for Metadata Harvesting)

* Dedicated Editorial Board for every journal

* Accurate and rapid peer-review process

* Increased citations of published articles through promotions

* Reduced timeline for article publication

Submit your articles and experience a new surge in publication services (https://www.peertechz.com/submission).

Peertechz journals wishes everlasting success in your every endeavours.

Copyright: (๑) 2020 Marco Antonio Benamú P. This is an open-access article distributed under the terms of the Creative Commons Attribution License, which permits unrestricted use, distribution, and reproduction in any medium, provided the original author and source are credited.

Citation: Marco Antonio Benamú P (2020) The importance of spider diversity in agroecosystems and the effect of pesticides. Glob J Ecol 5(1): 060-061. 